\title{
Henry Clay Binns, " Iowa Pioneer
}

\author{
Edited by Walter F. Peterson
}

Dr. Peterson, a great nephew of the late Charles R. Binns, is Chairman of the Department of History and of the Social Science Division of the Milwaukee-Downer College. $\mathrm{He}$ is a graduate of the State University of Iowa, and is currently working on the history of the Allis-Chalmers Manufacturing Company for the company.

Charles Robert Binns was born in Montgomery County, Iowa, on February 14, 1866 and died on September 20, 1959. His prosperous father successively bought him into a grocery store at Coburg, Iowa; a lumber yard at Essex, Iowa; a bank at Stanton, Iowa, and a hardware store at Omaha, Nebraska. His partner in the Omaha venture was an inventor, Lloyd Scruggs, who developed a copper lined kitchen range that would not burn out. The two men organized the Copper Clad Malleable Range Company in St. Louis, Missouri, about 1910; Lloyd Scruggs as the president and designer and Charles Binns as the vice-president and treasurer. He continued in that capacity until the company discontinued operations in the early nineteen-fifties.

During his latter years he dictated reminiscences to his secretary. Two of the manuscripts concerned his father, Henry Clay Binns, an Iowa pioneer. These two manuscripts have been edited and combined to form a single coherent statement of life in Iowa a century ago.

My father was born in Brownsville, Pennsylvania, in October, 1824, way back when James Monroe, the fifth in line, was President of the United States. His school education was very limited, for there were no free schools in those days. His education was obtained at home through the teaching of his parents. Fortunately his father was highly educated, as children of poor parents in those days were usually destined to grow up in ignorance.

My father started working while very young, contributing his earnings to the family budget. At the early age of 14 , he

-A brief formal biography of Henry Clay Binns (October 27, 1823February 1, 1918) was published in the Biographical History of Page County, Iouva, Chicago, 1890. 
started on his long career, first as a cabin boy on a steam-boat on the Monogahela River, plying between Brownsville and Pittsburgh. Young Henry evidently was very attentive for in the course of time he was promoted to a more lucrative and responsible position, that of clerk on a steam-boat on the Ohio River, plying between Pittsburgh and St. Louis. Those were the hectic days when steam-boating was at its zenith; when notorious gamblers and confidence men, known then as sharpers, booked passage continuously, preying upon innocent victims, fearless of any law; when the big rivers were the only means, other than stages and slow freight wagons, of providing travel and transportation reaching out into the immensity of the middle west; when the fertility of the new State of Iowa was invariably considered almost a wilderness and the broad expanse west of the Missouri River was universally known as the great American Desert.

The alluring stories about the fertile land in Iowa territory were being widely heralded, which evidently appealed to the visions of my father, eager to amass a fortune so luringly offered in the new state, for in 1851 he abandoned the river life and cast his lot with the settlers in Monroe County, Iowa, not far from where Ottumwa stands today.

He built a small log cabin and purchased a yoke of oxen and a prairie breaking plow, with a view of starting in a small way. Perhaps it was driving the slow moving oxen that became unbearably monotonous: it may have been the distasteful task of cooking his own meals, or it could have been the recollection of those luscious meals, served on the river steam-boat. Whatever the reason may have been, we were told that after one year, he disposed of his property and returned to the duties of chief clerk on a steam-boat.

His return to his former post was apparently only temporary for the magnetic attraction of the rich fertile soil of Iowa lured him to the south-western part of the state. In August, 1854, with three hundred dollars in gold as his total assets, he disembarked from a river steam-boat at a landing then known as Cainsville (now Council Bluffs) Iowa, a small trading post supporting a government land office. Tribes of Indians were encamped just opposite on the Nebraska side of the river, on the site where the City of Omaha now stands. 
Henry was a total stranger in a wild and strange land. He walked east from Cainsville following an Indian trail for about fifty miles, arriving at the Nishna-Botna River the next day about sun down. Placing his entire wealth of $\$ 300.00$ in gold in his boots and strapping them astride a small log bearing his cloths ( sic.), he swam the river to the opposite side, landing in soft mud with millions of hungry mosquitos swarming about.

I have been told that it was the unanimous opinion of the early settlers that all timber lands along the streams would eventually be settled upon, either through homesteading or direct purchase, and the vast prairie lands would remain open forever, thereby furnishing free grazing for the herds of settlers. How were they to know that in the future these same prairie lands were destined to become the most valuable.

He selected 160 acres, with plenty of timber and water, located on the extreme northern part of Page County. According to my father's story, there was only one white woman in the county at that time. Two years later, in 1856, Henry's father, his brothers and his sisters came out from Pennsylvania and the following spring, his mother came on from Indianapolis where she had been detained on account of sickness. When my Grandfather and his seven children, most of them grown, arrived, they moved into my father's one room cabin, with room to spare.

One of the most thrilling stories recounted by the old settlers, the one that always made shivers run up and down my spine, was their experiences during the severe winter of 1856 and ' 57 . The deep snow fall measuring considerably more than three feet, occurred in the early part of the winter completely blocking traffic of all kinds, and the small number of scattered settlers practically were unable to move about. Temperatures often dropped to an unprecedented low level, and raging blizzards were frequent throughout that long and never-to-be-forgotten winter. Overland stage coaches, which were the principle means of travel, necessarily were abandoned until the following spring with no delivery of mail for almost three months. Some of the settlers, including my grandfather's family, were wholly unprepared, entering the early winter with a very limited amount of meal for bread and 
consequently, through dire necessity, were compelled to grind their corn by hand on an old-fashion coffee mill throughout the entire winter, as the nearest grinding mill was located at Rockport, Missouri, about sixty miles away. Deer, wild turkeys and prairie chickens were plentiful and easily killed or trapped, furnishing the settlers with an ample and varied supply of wild meat.

It is also known that the loss of wild game, both animal and fowl, was extremely heavy during the severe winter, perishing through starvation and extreme cold. I am relating these incidents verbatim, as told to me by my father, and I wish to impress in the mind of the reader some of the many problems encountered and hardships endured by the early settlers of Western Iowa.

Here is a pathetic story my father told many times - In 1857 their meager crops were destroyed by locusts and grasshoppers. They had no wheat, their corn was gone, and they seemed to be facing starvation. To make the situation more discouraging, was the fact that they had no money; not even enough to buy a postage stamp. A man living over near Walnut Creek heard of the destruction and was willing to sell twenty bushels of corn to my father for forty dollars, taking his note drawing forty percent interest. The tragic part was, they lost it all while returning from the mill at Rockport, Missouri, where the corn had been ground into meal. Someone has a slogan-"When it rains, it pours." How true that was in that instance, for on their way home a heavy rain fell soaking the meal through and through, resulting in a total loss. When the story was told, the same man came forward and sold twenty bushels more taking my father's second note for forty dollars at forty percent interest.

In 1857, my father was unable to raise enough money to pay the tax on his land, which according to an old tax receipt found among his personal papers, amounted to $\$ 12.19$, including penalty and interest, but his land was not sold for taxes, because nobody wanted it. The first real money of importance they received, was six hundred dollars from the sale of potatoes to the Mormons, who were passing through on their way to Salt Lake, almost like a fabulous fortune.

Courage? Did these pioneers have it? At times I wonder 
if we really understand the meaning of the word, as did our forefathers.

On October 21, 1858, my father married Elizabeth A. Davis. Their five children were: Hester, William H., Lewis M., Charles R., and Jonathan. My mother, Lewis and Jonathan, all passed away in the same year, when I was two years old. After my mother passed away, I was sent to live with my grandmother, while my father's sisters alternated in looking after his household. On September 12, 1871, father married Maryette Weidman, a kind and loving woman, who, in my heart, so tenderly filled the place of mother.

In 1868 the first railroad penetrating southwestern Iowa came in from the East, ending temporarily at Red Oak, known then as Red Oak Junction. It was then that greater opportunities were offered and thereafter my father became more successful. He had increased his land holdings to 420 acres all clear of debt. In 1875, he purchased 320 acres, and in 1880, he purchased 120 acres totaling 860 acres. For many years, my father was a successful stockman and cattle feeder. Beside raising a great number of hogs and sheep, he usually fed two droves of cattle each year.

Long about 1870, his friends and neighbors, considered him as extravagant, when he built his first frame house, containing one room on the ground floor with a real stairway leading to the unfinished half story above. This was quite a departure from the old log cabin, that supported a ladder to its loft. But the climax came in 1880, when the logs of the old cabin were relegated to the woodpile, to make room for a large modern house with stone basement, a real monument in those days.

When the Red Oak National Bank was organized, he became a stockholder and director, and later its Vice-President, serving for many years. In 1888, two young men, E. B. Osborne and T. D. Murphy, fresh from the university, filled with visions, arrived in Red Oak and published a small weekly newspaper. They soon conceived the idea of printing an art calendar, the origin of this art. They needed capital for their enterprise, but had no established credit. My father came to the rescue and advanced the money to finance what later 
was to become the largest printing institution of its kind, the Osborne-Murphy Calendar Company.

In 1891, my father retired from the farm and moved into Red Oak. He disposed of the old home and other land except the 480 acres which he retained until his death in 1918.

I could not be so unmindful in closing without paying the highest tribute to him-my father. He cultivated friendship through his fairness and consideration for his fellow men. $\mathrm{He}$ was charitable to the needy; faithful to his family; loyal to his country and honest with himself. When I thumb through the pages of history, and turn back to that day in August, 1854, when he walked across the prairie to the Page County line; how he fiercely fought the fangs of starvation in 1857; how he finally emerged from the pangs of poverty to a life of comfort, I am thankful and proud of the right to bear his honored name.

\section{The Turnverein}

The local turnverein or gymnastic society was at one time quite common in Iowa. German settlers brought the institution from their homeland in the belief that physical training and exercise was an essential part of the educational system. Members of these clubs held regular public meetings in German for the purpose of exercise and drill.

The turnverein at Holstein met in a hall above a store for some time after its organization in the 1880 's. A new building containing a gymnasium equipped with the most modern apparatus was erected in 1890. Classes were held every evening, two nights for the men, two for boys, two for the ladies, and the afternoons given to the children after the dismissal of public school. Qualified instruction was provided by Prof. Carl L. Jones, a graduate of the German-American College at Milwaukee, which provided many teachers for these turnvereins. Holstein's Turner Hall gave an exhibition each fall and spring, and also entered a team in the state turnfest. Its activities were well patronized, and by 1905 had a membership of 170 , contributing much to the spirit and progress of the community. 
Copyright of Annals of Iowa is the property of State of Iowa, by \& through the State Historical Society of Iowa and its content may not be copied or emailed to multiple sites or posted to a listserv without the copyright holder's express written permission. However, users may print, download, or email articles for individual use. 